\title{
Caprylic acid suppresses inflammation via TLR4/NF-KB signaling and improves atherosclerosis in ApoE-deficient mice
}

\author{
Xinsheng Zhang ${ }^{1,2}$, Changyong Xue ${ }^{2}$, Qing X ${ }^{2}$, Yong Zhang ${ }^{2}$, Huizi Li ${ }^{3}$, Feng Li ${ }^{4}$, Yinghua Liu ${ }^{2^{*}}$ and \\ Changjiang Guo ${ }^{1 *}$
}

\begin{abstract}
Background: As reported previously by our group, medium-chain triglycerides can ameliorate atherosclerosis. Given that TLR4 is closely related to atherosclerosis, we hypothesized herein that caprylic acid (C8:0) would suppress inflammation via TLR4/NF-KB signaling and further promote the amelioration of atherosclerosis in apoEdeficient $\left(\mathrm{apoE}^{-/-}\right)$mice.

Methods: Fifty 6-week male apoE ${ }^{-/-}$mice were randomly allocated into five diet groups: a high-fat diet (HFD) without or with 2\% caprylic acid (C8:0), capric acid (C10:0), stearic acid (C18:0), or linolenic acid (C18:3). RAW246.7 cells were treated with caprylic acid (C8:0), docosahexenoic acid (DHA), palmitic acid (C16:0), and lipopolysaccharide (LPS) with or without TLR4 knock-down (TLR4-KD). The serum lipid profiles, inflammatory biomolecules, and mRNA and protein expression levels were measured. Atherosclerotic lesions that occurred in the aorta and aortic sinuses were evaluated and quantified.
\end{abstract}

Results: Our results indicated that C8:0 reduced body fat, improved the lipid profiles, suppressed inflammatory cytokine production, downregulated aortic TLR4, MyD88, NF-KB, TNF-a, IKKa, and IKKB mRNA expression, and alleviated atherosclerosis in the apoE ${ }^{-/-}$mice $(P<0.05)$. In RAW 264.7 cells, $C 8: 0$ diminished the inflammatory response and both mRNA and protein expression of TLR4, MyD88, NF-KB, and TNF-a compared to those in the LPS and $16: 0$ groups $(P<0.05)$. However, in the TLR4-KD RAW 264.7 cells, C8:0 significantly upregulated NF-KB mRNA and protein expression compared to those in the C16:0 and DHA groups.

Conclusions: These results suggest that C8:0 functions via TLR4/NF-KB signaling to improve the outcomes of $\mathrm{apo}^{-/-}$mice through suppressing inflammation and ameliorating atherosclerosis. Thus, C8:0 may represent as a promising nutrient against chronic inflammatory diseases.

Keywords: Caprylic acid, Inflammation, TLR4, Atherosclerosis, apoE-deficient mice

\section{Introduction}

Atherosclerosis is a chronic inflammatory disease that is characterized by lipid accumulation, smooth muscle cell proliferation, cell apoptosis, necrosis, fibrosis, and local inflammation [1, 2]. Fatty acids have been deemed important dietary factors that affect the occurrence and development of this condition, and different aliphatic acids

\footnotetext{
*Correspondence: liuyinghua77@163.com; guocjtj@126.com

2Department of Nutrition, Chinese PLA General Hospital, 28 Fuxing Road, Beijing 100853, China

${ }^{1}$ Department of Nutrition, Tianjin Institute of Environmental \& Operational Medicine, Tianjin 300050, China

Full list of author information is available at the end of the article
}

can contribute to inflammation and atherosclerosis via diverse pathways. Pro-inflammatory genres, such as saturated fatty acids (SFAs) $[3,4]$ and $n-6$ polyunsaturated fatty acids (PUFAs), can induce atherosclerosis, whereas n-3 fatty acids that are rich in fish oil, such as docosahexaenoic acid (DHA) and eicosapentaenoic acid (EPA), can inhibit many aspects of inflammation, including leucocyte chemotaxis, adhesion molecule expression and leucocyte-endothelial adhesive interactions $[5,6]$. These effects of n-3 fatty acids can lower the morbidity of atherosclerosis and contribute to the prevention of cardiovascular disease (CVD) -related complications [7]. 
Medium-chain fatty acids (MCFAs), such as caprylic acid (C8:0), capric acid (C10:0), and lauric acid (C12:0), carry a backbone chain with 8 to 12 carbon atoms. MCFAs, in the form of medium-chain triglycerides (MCTs) that are present in milk fat, palm oils, coconuts, and cuphea seed oils $[8,9]$. MCFAs have been increasingly noted to be quite different from long-chain fatty acids (LCFAs) both physically and metabolically, although they both belong to the SFAs. Specifically, MCFAs can reduce body fat accumulation [10-12] and improve cholesterol metabolism [13-15]. We found that, in contrast to the LCFAs, MCTs (50\% C8:0 and 50\% C10:0) have a potential for reducing serum LDL-C and TC levels and improving HDL-C levels in hypertriglyceridemic subjects $[12,16]$. We also observed that MCTs could ameliorate atherosclerosis in apoE-deficient $\left(a p o E^{-/-}\right)$mice [17]. Nevertheless, the impact of MCFAs on inflammation and atherosclerosis awaits further investigation.

The Toll-like receptor 4 (TLR4) /nuclear factor kappa $\mathrm{B}(\mathrm{NF}-\mathrm{kB})$ pathway has significant functions in the stress response and inflammation, and recently it has been suggested to be closely related to human atherosclerosis $[18,19]$. TLR4 expression has been observed in smooth muscle cells, vascular endothelial cells, and macrophages [20]. Triggered by TLR4 ligands, it activates the subsequent NF- $\mathrm{BB}$ signaling pathway, which increases gene transcription of many pro-inflammatory factors. Moreover, Michelsen et al. have proven that knock out of TLR4 can reduce atherosclerotic lesions in the aorta to a great extent and reduce the levels of circulating pro-inflammatory cytokines in apo: $\mathrm{E}^{-/-}$mice [21].

Based on former studies, C8:0 herein is hypothesized to suppress the inflammatory reaction via TLR4/NF- $\mathrm{kB}$ signaling and to alleviate the atherosclerotic state in $\mathrm{apoE}^{-/-}$mice. To test it, we carried out a further investigation into the effects of C8:0 on inflammation, mRNA and protein expression of TLR4/NF- $\mathrm{kB}$ pathway components, and the atherosclerotic condition of apoE ${ }^{-/-}$mice. These effects were also investigated in RAW246.7 cells with or without TLR4 knock-down (TLR4-KD).

\section{Materials \& methods \\ Materials}

MCFAs samples of C8:0, C10:0, as well as LCFAs samples of palmitic acid (C16:0), stearic acid (C18:0), and alpha linolenic acid (C18:3) were obtained from Sigma-Aldrich (St. Louis, MO, USA). Lipopolysaccharide (LPS), DHA, bovine serum albumin (BSA), oil red O, fetal bovine serum (FBS) and DMEM culture medium were provided by Gibco (Grand Island, Nebraska, USA). OCT compound was from Tissue Tek (Sakura, Torrance, CA). Other reagents were available at Sigma-Aldrich.

\section{Animal experiments}

Fifty 4-week-old male apoE ${ }^{-/-}$mice were obtained from Shanghai Model Organism (License SYXK 2018-0002) and bred in polycarbonate cages (temperature $21-23^{\circ} \mathrm{C}$, humidity $40-60 \%, 5$ animals per cage) on a 12-h light-dark cycle. A basal diet was applied for animal adaptation for more than a week. Then, all the 50 mice ( 6 weeks old) were randomly divided into 5 groups $(n=10)$ : high-fat diet (HFD) with $2 \%$ C8:0, HFD with $2 \%$ C10:0, HFD with $2 \%$ C18:0, HFD with $2 \%$ C18:3, and HFD alone. The ingredients list, amount of nutrients, and specific fatty acid compositions of all diets in this work are provided in additional files [see Additional file 1, 2]. Beijing Institute of Nutrition examined the dietary nutrients, and analyzed the dietary lipids with gas-liquid chromatography, as described in detail in our previous report [17].

The body weight and food intake of mice was recorded weekly. Feeding was maintained continuously for 16 weeks, followed by a fasting for more than $8 \mathrm{~h}$ (except for water). Subsequently, mice were euthanized via intramuscularly injection with xylazine hydrochloride (10 $\mathrm{mg} / \mathrm{kg}$ ) for blood sampling from the abdominal and collection of tissues for detailed assays.

\section{Measurement of serum lipid profiles}

Commercial kits were employed to test serum TC and triglycerides (TG) (Wako, Osaka, Japan), to detect the level of HDL-C and LDL-C by means of sediment approach (Abcam, Cambridge, UK), and to evaluate the serum level of total bile acid (TBA) (Blue Gene, Shanghai, China). Ratio of HDL-C to LDL-C was subsequently calculated. All the measurements were performed strictly following the instructions from the manufacturer.

\section{Measurement of inflammatory cytokines in plasma} ELISA kits (R\&D Systems, Minneapolis, MN, USA) were utilized to determine the plasma interleukin-1 $\beta$ (IL-1 $\beta$ ), interleukin-2 (IL-2), interleukin-6 (IL-6), interleukin-10 (IL-10), monocyte chemoattractant protein-1 (MCP-1) and TNF- $\alpha$ levels following the instructions from the manufacturer.

\section{Assessment of atherosclerosis in the aorta and aortic sinus}

At the end of the study, five mice were randomly chosen from each group to estimate the atherosclerotic plaque areas using a previously reported method [17]. The dissected aorta from the root to the abdominal region was fixed in formalin after a careful removal of all connective tissues. A longitudinal incision was made over the rest of the entire aorta, followed by pinning in a posture with the lumen side up. After staining the aorta with oil red $\mathrm{O}$, digital photographs were taken. Image-Pro Plus 6.0 was used to measure the total surface area and the total 
oil red O-positive lesion area. The percentage of the lesion areas to the total areas was used to assess the extent of atherosclerotic lesion.

The aortic root tissue frozen in O.C.T. was cut into $10 \mu \mathrm{m}$ serial sections, and the total oil red O-positive lesion area was measured by NanoZoomer Digital Pathology 2.0 (Hamamatsu, Japan).

\section{Real-time PCR analysis}

To analyze the RNA expression levels, cells were harvested while aorta samples (approximately $50 \mathrm{mg}$ ) were rinsed with PBS at low temperature (on ice), followed by homogenization. Total RNA was isolated using TRIzol reagent from Omega Bio-Tek (Norcross, GA, USA), and qRT-PCR analysis was conducted subsequently. The Moloney murine leukemia virus reverse transcriptase (Invitrogen, CA, USA) was employed for cDNA preparation with RNA $(1 \mu \mathrm{g})$ as the raw material. The obtained cDNA was subjected to qRT-PCR analysis in a fluorometric thermal cycler using the Line-Gene fluorometric PCR detection system (BoRi Technology, China) and the BioEasy Master mix (SYBR Green). The initial denaturation was performed for the reactant mixtures via a 2-min incubation at $95^{\circ} \mathrm{C}$, followed by 45 cycles comprising $95^{\circ} \mathrm{C} / 20 \mathrm{~s}, 59^{\circ} \mathrm{C} / 25 \mathrm{~s}$, and $72{ }^{\circ} \mathrm{C} / 30 \mathrm{~s}$. The Primer Express 3.0 software was utilized for primer design (Table 1).

Relative quantification was performed through the $\Delta \mathrm{Ct}$ method, with the difference in $\mathrm{Ct}$ between the reference gene $(\beta$-actin) and the target gene equaling the $\Delta \mathrm{Ct}$ values for the tested samples. For each sample, target gene expression was normalized according to the eq.

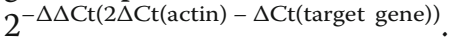

\section{Fatty acid preparation}

Fatty acids were prepared referring to the operational details in our previous report [17]. Briefly, stock solutions $(20 \mathrm{mmol} / \mathrm{L})$ of $\mathrm{C} 8: 0, \mathrm{C} 16: 0$, and DHA were procured by dissolving a preset amount of solute in ethanol.
The samples were diluted to $2 \mathrm{mmol} / \mathrm{L}, 1 \mathrm{mmol} / \mathrm{L}$, and $0.5 \mathrm{mmol} / \mathrm{L}$ for practical use with cell culture medium containing $20 \mathrm{mg} / \mathrm{L}$ endotoxin-free BSA. Before cell addition, the obtained solutions were incubated for $1 \mathrm{~h}$ at $37^{\circ} \mathrm{C}$.

\section{RAW 264.7 cell experiments}

The RAW 264.7 cell line was provided by Peking Union Medical College. Cell cultivation was performed in a humidified incubator (95\% air, $5 \% \mathrm{CO}_{2}, 37^{\circ} \mathrm{C}$ ) in DMEM supplemented with heat-inactivated FBS (10\%), L-glutamine $(2 \mathrm{mmol} / \mathrm{L})$, vitamins $(1 \times)$, and antibiotics (streptomycin, $100 \mathrm{~g} / \mathrm{L}$ and penicillin, $100 \mathrm{U} / \mathrm{mL}$ ).

The cells were cultivated for $24 \mathrm{~h}$ in 24 -well plates at a density of $1.5 \times 10^{5}$ cells/well. The cultivation medium was refreshed with new medium containing LPS (100 $\mathrm{ng} / \mathrm{mL}$ final concentration) supplemented with C8:0, C16:0, or DHA. Another round of cell incubation was carried out for 12,24 , or $48 \mathrm{~h}$, respectively. The following RAW264.7 treatment groups were included: (1) control; (2) LPS; (3) LPS + C8:0 $(50 \mu \mathrm{mol} / \mathrm{L}) ;(4) \mathrm{LPS}+\mathrm{C} 8: 0$ $(100 \mu \mathrm{mol} / \mathrm{L}) ; \quad(5) \quad \mathrm{LPS}+\mathrm{C} 8: 0 \quad(200 \mu \mathrm{mol} / \mathrm{L}) ; \quad(6) \mathrm{LPS}+$ C16:0 $(100 \mu \mathrm{mol} / \mathrm{L})$; and (7) LPS + DHA $(100 \mu \mathrm{mol} / \mathrm{L})$. Afterwards, the cells were washed with PBS at low temperature (on ice) three times for media removal, and ELISA kits were employed for measurement of TNF- $\alpha$, MCP-1, IL- $1 \beta$ and IL- 6 in the cell lysates, following the manufacturer's instructions. These experiments were repeated, and the cells were harvested. Finally, proteins and RNA were isolated to analyse the expression of TLR4, MyD88, NF- $\kappa$ B, and TNF- $\alpha$.

\section{TLR4-KD in RAW 264.7 cells}

The RAW264.7 cells $\left(1.5 \times 10^{5}\right.$ cells/well $)$ were transfected with a plasmid encoding a TLR4 siRNA (Invivogen, USA) utilizing the Lipofectamine 2000 reagent (Life Technologies, USA) following the manufacturer's instructions. Then, G418 $(500 \mu \mathrm{g} / \mathrm{mL})$ was employed for isolating stable transfectants after a 3-week selection. A limited dilution method

Table 1 Primer sequences in qRT-PCR

\begin{tabular}{llll}
\hline Gene & Sense primer $\left(5^{\prime}-3^{\prime}\right)$ & Antisense primer (5'-3') & Accession No. \\
\hline TLR4 & TCAGTTCTCACCTTCCTCCTG & GTTCATTCCTCACCCAGTCTTC & GQ_503242.1 \\
MyD88 & GATGGTAGCGGTTGTCTCTGAT & GATGCTGGGGAACTTCTTC & AB292176.1 \\
NF-KB & AGTACCCTGAGGCTATAACTCGC & TCCGCAATGGAGGAGAAGTC & EU399817.1 \\
TNF-a & TCCAATGGCAGAGTGGGTATG & AGCTGGTTGTCTTTCAGCTTCAC & NM_214022.1 \\
TAK1 & GAAGGTGGATCCCTGCACAA & CATGCAAATATGCCAGGCCC & XM_002101880.2 \\
MAPK & GCTGAAGCGCCATTCAAGTT & CCTCTGAGCCCTTGTCCAAT & NM_001357115.1 \\
IKKa & GGCTGGACAGCGTCTCTTTA & GGTGGAAGATGGAGCCAGAC & NM_001044308.2 \\
IKKB & GTGCCTGTGACAGCTTACCT & ACTGCGTTTGCACTTTTGCT & NM_010546.2 \\
\hline
\end{tabular}

TLR4 toll-like receptor 4, MyD88 myeloid differentiation primary response $88, N F-K B$ nuclear factor kappa $B$, TNF- $\alpha$ tumor necrosis factor alpha, TAK1 TGF- $\beta$ activated kinase 1, MAPK mitogen-activated protein kinase, IKKa inhibitor kappa B kinase a, IKK $\beta$ inhibitor kappa $B$ kinase $\beta$ 

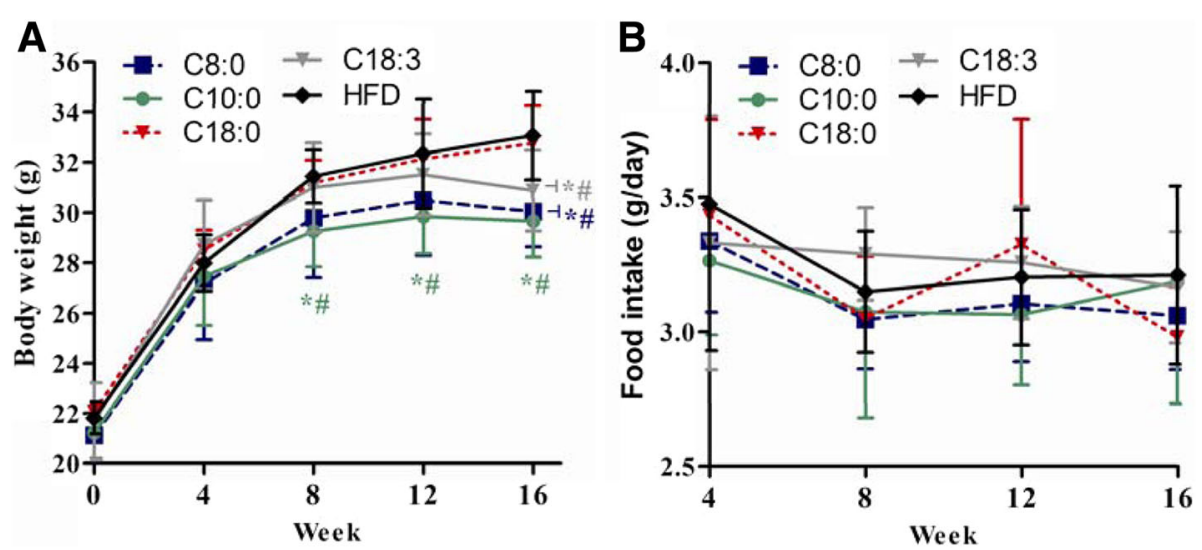

Fig. 1 Body weight and food intake of the apoE ${ }^{-/}$mice. (a) Fasting body weight was determined once per month; (b) Food intake during the experiment. Data are mean \pm S. D of the mean $(n=10) .{ }^{*} p<0.05$ versus HFD group; ${ }^{*} p<0.05$ versus C18:0 group

was applied to isolate single clones of stably transfected cells. One stable clone resistant to G418 was kept in G418 $(500 \mu \mathrm{g} / \mathrm{mL})$-containing medium. DMEM containing $10 \%$ FBS was utilized throughout the experimental operation, followed by refreshment with medium containing LPS (100 $\mathrm{ng} / \mathrm{mL}$ final concentration). The cells were incubated for another $24 \mathrm{~h}$ after the addition of C8:0, C16:0, or DHA into the culture medium. The following RAW264.7 cell with TLR4-KD treatment groups were included: (1) control; (2) TLR4-KD; (3) TLR4-KD + LPS; (4) TLR4-KD + LPS + C8:0 $(100 \mu \mathrm{mol} / \mathrm{L}) ; \quad$ (5) $\quad$ TLR4-KD + LPS + C16:0 $\quad(100 \mu \mathrm{mol} / \mathrm{L})$; and (6) TLR4-KD + LPS + DHA $(100 \mu \mathrm{mol} / \mathrm{L})$. Then, ELISA kits were employed to assess the TNF- $\alpha$, MCP-1, IL- $1 \beta$ and IL-6 levels in the cell lysates, following the instructions from the manufacturer. These experiments were repeated before further analyzing the expression of TLR4, MyD88, NF- $\mathrm{kB}$, and TNF- $\alpha$ by centrifugation and collection of protein and total RNA.

\section{Western blotting analysis}

The cells were cultured for $24 \mathrm{~h}$ in 24 -well plates at a density of $1.5 \times 10^{5}$ cells/well. The cultivation medium
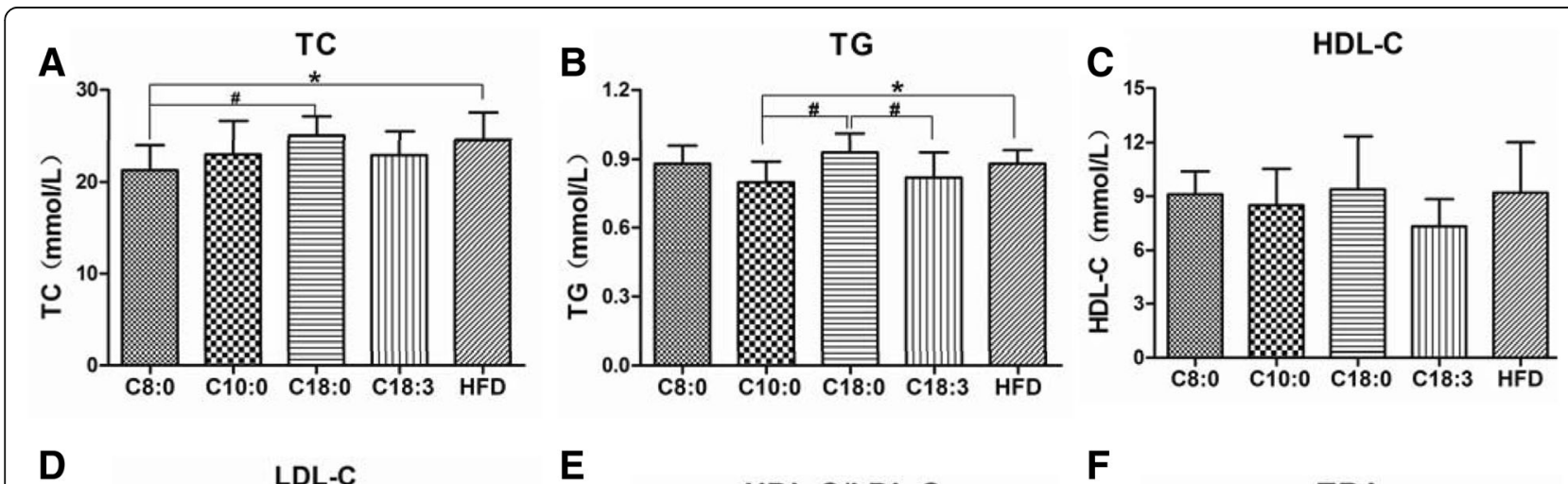

D

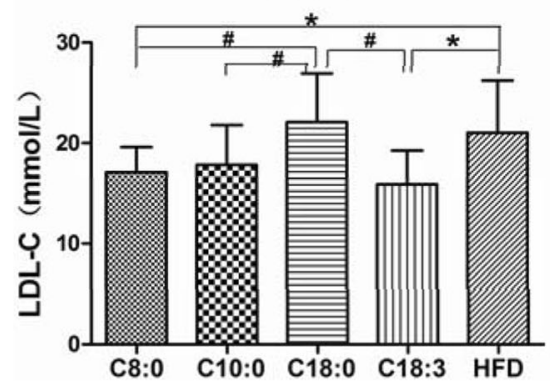

E

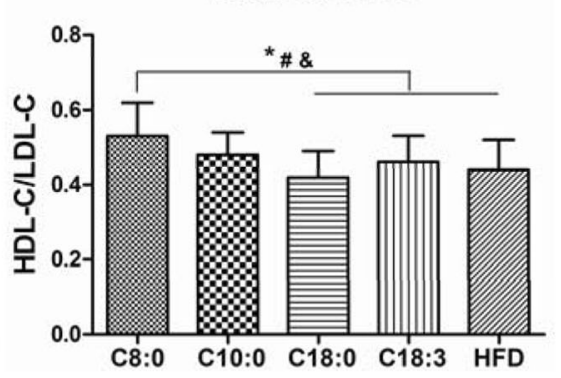

F

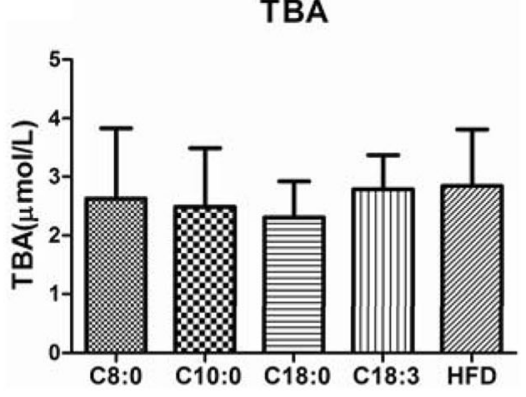

Fig. 2 Serum lipid profiles in the apoE ${ }^{-/-}$mice. (a) TC, (b) TG, (c) HDL-C, (d) LDL-C, (e) HDL-C/LDL-C, (f) TBA. Data are mean $\pm S$. D of the mean $(n=10) .{ }^{*} p<0.05$ versus HFD group; ${ }^{\#} p<0.05$ versus $C 18: 0$ group; ${ }^{\$} p<0.05$ versus $C 18: 3$ group 
was refreshed with new media containing LPS (100 $\mathrm{ng} / \mathrm{mL}$ final concentration). Another round of cell incubation was performed for $24 \mathrm{~h}$ after the addition of C8:0, C16:0, or DHA. Western blotting analysis of the cultured cells was performed as previously described [22]. Briefly, 30-min harvest and cell lysis were conducted on ice with NP40 cell lysis buffer containing a protease inhibitor cocktail $(1 \times)$ and phenylmethylsulfonyl fluoride $(1 \mathrm{mM})$. Then, a BCA Protein Assay Kit (Pierce Chemical Company, IL, USA; no. 23225) was employed for evaluation of the protein content in the supernatant. SDS-PAGE was applied to separate $25 \mu \mathrm{g}$ of protein extract, which was transferred subsequently to PVDF membranes. After an overnight block at $4{ }^{\circ} \mathrm{C}$ in TBS-Tween solution containing 5\% milk, the membranes were incubated with the primary antibodies for $2 \mathrm{~h}$. The primary antibodies against TLR4 (ab183459, 1:1000), MyD88 (ab2064, 1:1000), NF-kB (ab32360, 1:1000), TNF- $\alpha$ (ab6671, 1:1000), and $\beta$-actin (ab6276, 1:5000) were provided by Abcam (Cambridge, MA, USA). Afterwards, the membranes were thoroughly rinsed and subjected to another $2 \mathrm{~h}$ of incubation (room temperature) with a HRP-conjugated secondary antibody diluted 1:2000 in blocking buffer. A chemiluminescence detection system (GE Healthcare, Bucks, UK) was employed for observation of protein bands.

\section{Statistical analysis}

Based on a preliminary experiment, the G*Power 3.1.9.2 software (Heinrich-Heine University, Germany) was applied to calculate the minimum sample size required for the detection of a significant difference $(P<0.05)$. A minimum of 10 mice per group was needed for animal experiments. The numbers of samples required for the analysis of the blood lipid profiles, inflammatory cytokines, degree of atherosclerosis in the aorta and aortic sinus and PCR were 10, 10, 5, 5 and 5, respectively. The power calculation indicated a minimum of 6 for the cell experiments. All data in this report are presented as mean \pm standard derivation. One-way analysis of variance was performed for data analysis. The independent t-test that decided the statistical significance of differences among various groups as indicated by $P<0.05$ (two-tailed) was performed with SPSS 19.0 (SPSS, Inc., Chicago, IL, USA).

\section{Results}

Body weight and food intake of apoE ${ }^{-/-}$mice

For both humans and animals, MCTs or MCFAs have been found to suppress the increment of the body fat mass as well as the overall body weight [11, 23, 24]. Our previous study showed similar results in $\mathrm{ApoE}^{-/-}$mice [17]. In this work, the mice in the C10:0 group had much lower body weights than those in the C18:0 and
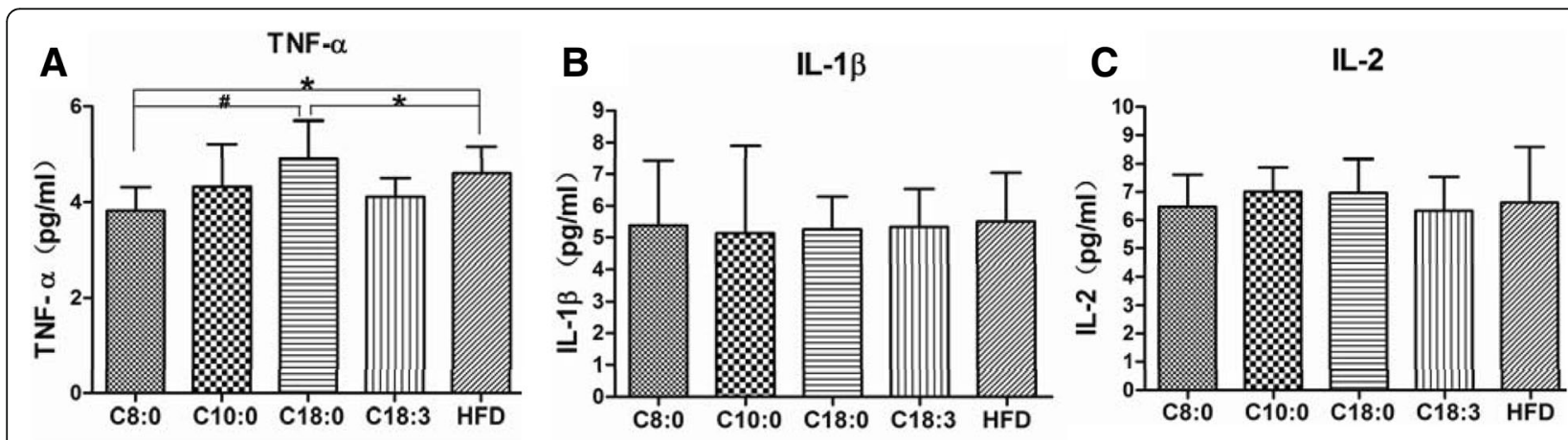

D

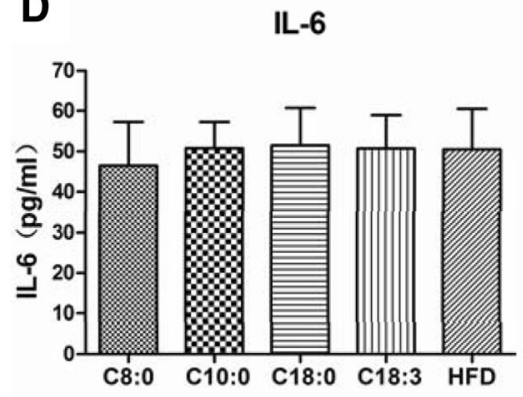

E

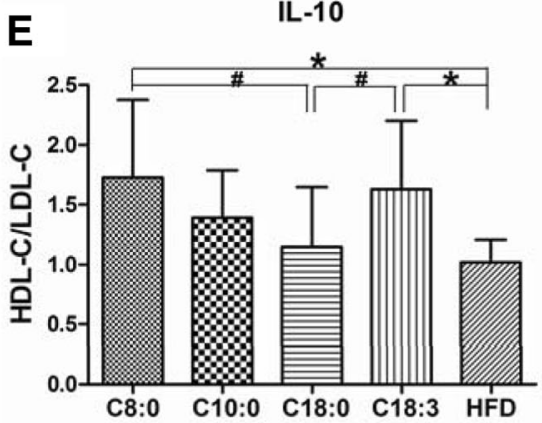

$\mathbf{F}$

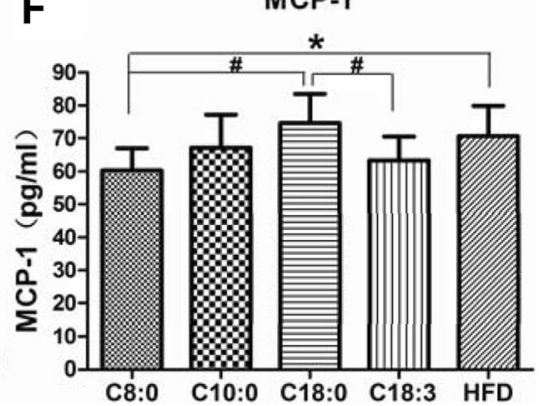

Fig. 3 The serum inflammatory cytokine levels in the apoE ${ }^{-/-}$mice. (a) TNF-a, (b) IL-1 $,(\mathbf{c}) I L-2,(\mathbf{d}) I L-6,(\mathbf{e}) I L-10,(\mathbf{f}) M C P-1$. Data are mean $\pm S$. D of the mean $(n=10)$. ${ }^{*} p<0.05$ versus HFD group; ${ }^{\#} p<0.05$ versus $C 18: 0$ group 

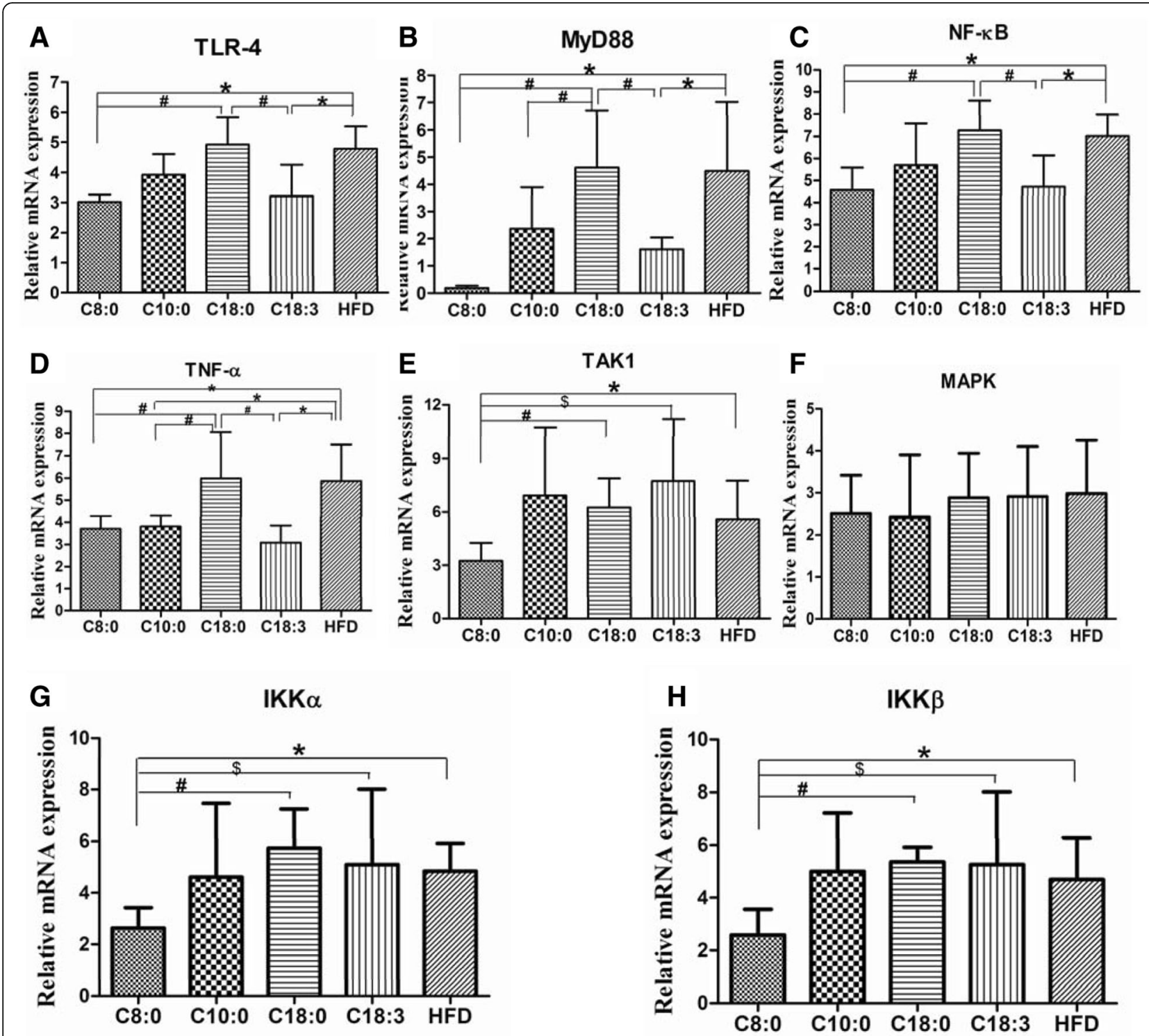

Fig. 4 The mRNA expression levels of TLR4/NF-KB signaling components in the apoE ${ }^{-/-}$mouse aorta. (a) TLR4, (b) MyD88, (c) NF-KB, (d) TNF-a, (e) TAK1, (f) MAPK, (g) IKKa, (h) IKKß. Data are mean \pm S. D of the mean $(n=5) .{ }^{*} p<0.05$ versus HFD group; ${ }^{\#} p<0.05$ versus C18:0 group; ${ }^{\$} p<0.05$ versus C18:3 group

HFD groups after 8 weeks; additionally, the body weight of the mice in the C8:0 and C18:3 groups were significantly lower than those of the C18:0 and HFD groups mice at 16 weeks (Fig. 1a). No significant differences were observed in the average daily food intake (Fig. 1b).

The serum lipid profiles in the apoE $\mathrm{E}^{-/-}$mice

Next, we determined the effects of a HFD containing different fatty acids (at $2 \%$ ) on the serum lipid profiles of the apoE ${ }^{-/-}$mice after 16 weeks. The C8:0 group mice had a significantly higher HDL-C to LDL-C ratio than the mice in the HFD (1.20-fold), C18:0 (1.26-fold) and C18:3 (1.15-fold) groups (Fig. 2e). The TC (Fig. 2a) and LDL-C (Fig. 2d) levels in the C8:0 group were significantly lower than those in the HFD and C18:0 groups. C8:0 could significantly improve blood lipids, especially the TC and LDL-C levels, which were similar to the findings in the C18:3 group. However, no significant differences were found in the TG, HDL-C, and TBA levels (Fig. 2b, c, and f).

Serum inflammatory cytokine levels in the apoE ${ }^{-/-}$mice Promoted release of different pro-inflammatory cytokines can be achieved by TLR4/NF- $\mathrm{kB}$ signaling activation. According to Fig. 3, the TNF- $\alpha$ (Fig. 3a) and MCP-1 (Fig. 3f) expression levels were lower and IL-10 (Fig. 3e) expression was enhanced in the plasma of the C8:0 group, compared with those of the C18:0 and HFD 


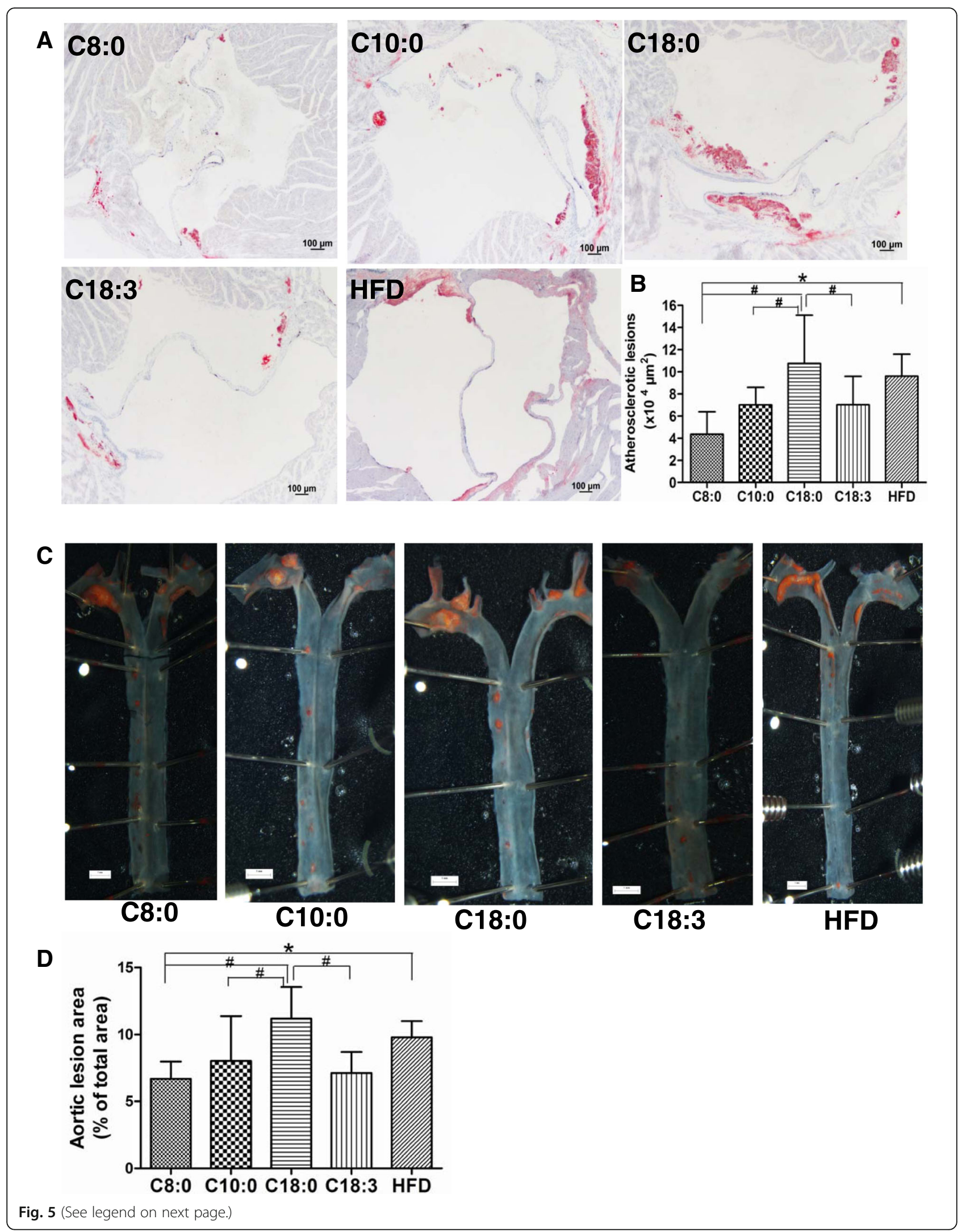


(See figure on previous page.)

Fig. 5 The degree of atherosclerosis in the aorta and aortic sinus in the apo: $\mathrm{E}^{-/-}$mice. (a) Cross-sections of aortic sinus which were stained by Oil Red $\mathrm{O}(\times 80)$ (scale bars equal to $100 \mu \mathrm{m}$ ) and (b) corresponding quantitative analysis on dye-positive areas. (c) Representative photographs of aortic lumen stained by Oil Red $\mathrm{O}(\times 5)$ (scale bars equal to $1 \mathrm{~mm}$ ) and $(\mathbf{d})$ Quantitative analysis of oil red O-positive areas of the aortic lumen relative to total aortic areas. Data are mean \pm S. D of the mean $(n=5)$. ${ }^{*} p<0.05$ versus HFD group; ${ }^{\#} p<0.05$ versus C18:0 group

groups. C8:0 significantly ameliorated inflammation in the $\mathrm{apoE}^{-/-}$mice, which were similar to observations in the $\mathrm{C} 18: 3$ group.

The mRNA expression levels of TLR4/NF-KB signaling components in the apoE ${ }^{-/-}$mouse aortas

Compared with those of the HFD and C18:0 groups, mRNA expression of TLR4, MyD88, NF- $\mathrm{kB}$, TNF- $\alpha$, TAK1, IKK $\alpha$, and IKK $\beta$ was significantly downregulated in the C8:0 group (Fig. 4). A similar trend was observed for the mRNA expression levels of TLR4, MyD88, NF- $k B$, and TNF- $\alpha$ in the C18:3 group (Fig. 4). These findings suggested that $\mathrm{C} 8: 0$ can inhibit the activation of the TLR4/NF- $\mathrm{kB}$ signaling pathway in the aorta of $\operatorname{apoE}^{-/-}$mice.

Atherosclerosis in the aorta and aortic sinus of the apoE $^{-/-}$mice

As presented in Fig. 5, a decrease was found in both the cross-sectional aortic sinus and whole aorta atherosclerotic lesions in the C8:0 group, compared with those of the C18:0 group (59 and 40\% decreases, respectively) and HFD group (55 and $32 \%$ decreases, respectively). In addition, the aortic sinus plaque and whole aorta areas were significantly less in the $\mathrm{C} 10: 0$ and $\mathrm{C} 18: 3$ groups than in the C18:0 group (Fig. 5b, d).

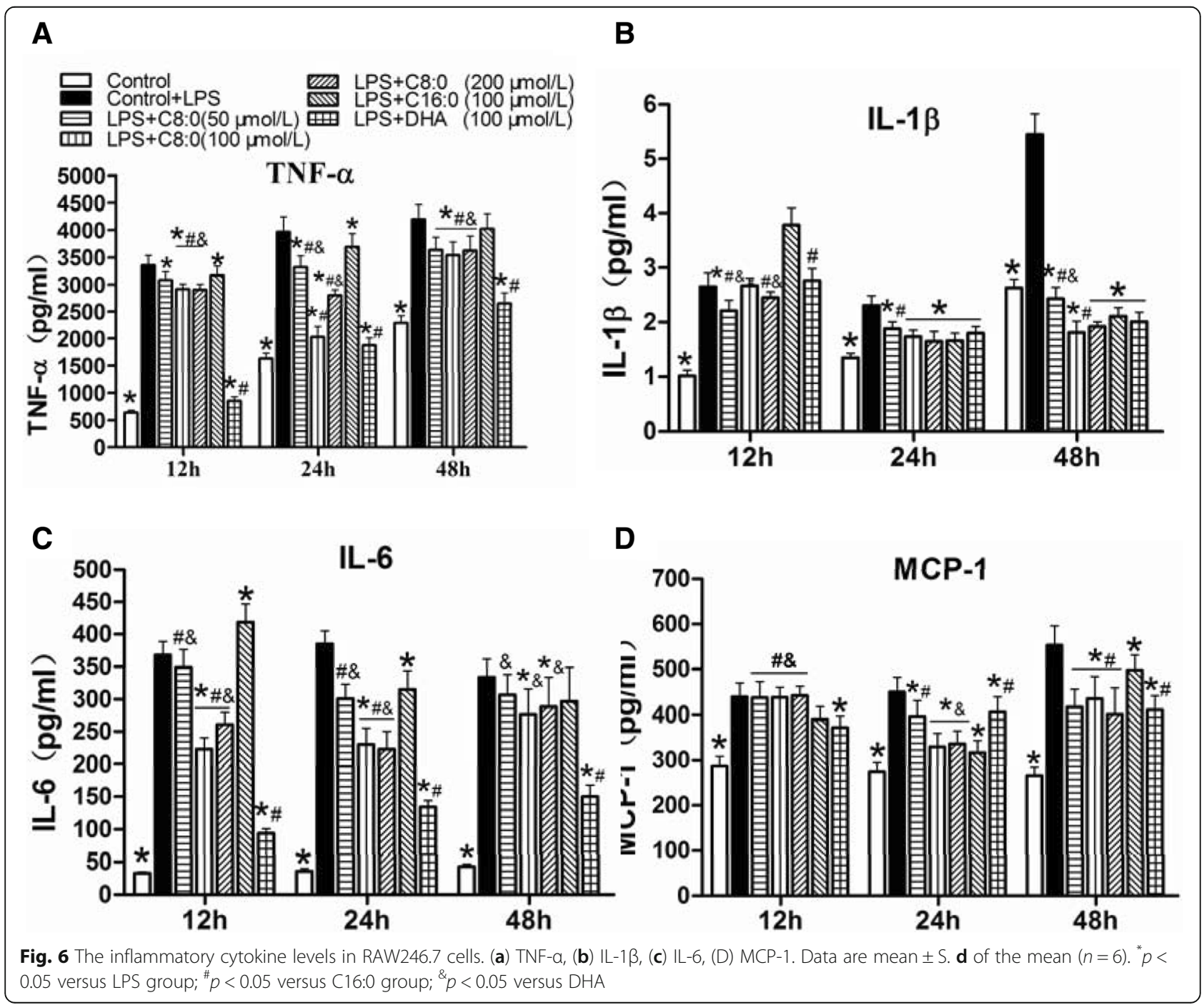



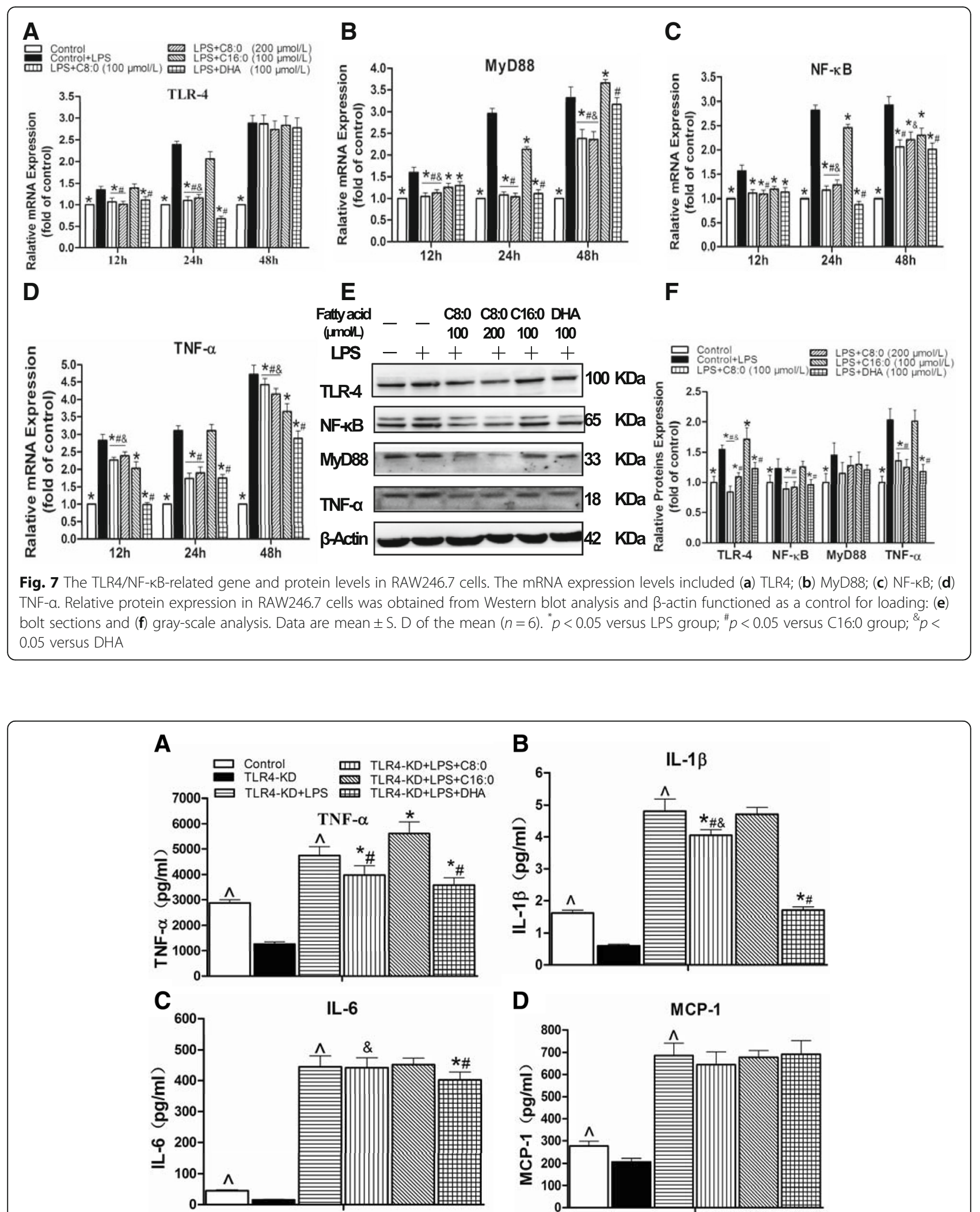

Fig. 8 The inflammatory cytokine levels in TLR4-KD RAW246.7 cells. The inflammatory cytokines included (a) TNF-a, (b) IL-1 3 , (c) IL-6, (d) MCP-1. Data are mean $\pm S$. $D$ of the mean $(n=6)$. $p<0.05$ versus TLR4-KD group; ${ }^{*} p<0.05$ versus TLR4-KD + LPS group; ${ }^{*} p<0.05$ versus TLR4-KD + LPS + C16:0 group; ${ }^{\&} p<0.05$ versus TLR4-KD + LPS + DHA group 
Inflammatory cytokines and TLR4/NF-KB-related gene and protein expression levels in RAW246.7 cells

The TNF- $\alpha$ (2.4-fold), IL-1 $\beta$ (1.3-fold), IL-6 (10.7-fold), and MCP-1 (1.6-fold) levels (Fig. 6), the TLR4 (2.4-fold), MyD88 (3.0-fold), NF-кB (2.8-fold) and TNF- $\alpha$ (3.1-fold) mRNA expression levels (Fig. 7a-d) and the TLR4 (1.6-fold), MyD88 (1.2-fold), NF-kB (1.5-fold) and TNF- $\alpha$ (2.0-fold) protein expression levels (Fig. 7f) were significantly increased in the LPS-induced RAW246.7 cells than in the control group after $24 \mathrm{~h}$ of intervention. Therefore, the influences of various fatty acids on RAW246.7 cells stimulated with LPS were further elucidated. The inhibitory effect of C8:0 on inflammation was most obvious at the $100 \mu \mathrm{mol} / \mathrm{L}$ concentration for a duration of $24 \mathrm{~h}$, The comparison with the LPS groups indicated that the C8:0 group exhibited inhibited production of TNF- $\alpha$ (decreased by 49\%) (Fig. 6a), IL-1 $\beta$ (decreased by $25 \%$ ) (Fig. 6b), IL-6 (decreased by $40 \%$ ) (Fig. 6c), and MCP-1 (decreased by 26\%) (Fig. 6d) and downregulated TLR4 (decreased by 54\%) (Fig. 7a), MyD88 (decreased by 64\%) (Fig. 7b), NF-kB (decreased by 59\%) (Fig. 7c), and TNF- $\alpha$ (decreased by 44\%) (Fig. 7d) mRNA expression and TLR4 (decreased by 46\%), NF- $\mathrm{kB}$ (decreased by $21 \%$ ), and TNF- $\alpha$ (decreased by $33 \%$ ) (Fig. 7e, f) protein expression compared with the levels of the $\mathrm{C} 16: 0$ group $(p<0.05)$. These findings indicated that C8:0 directly affected TLR4-mediated inflammatory responses, which were similar to observations for the DHA group. However, compared with those of DHA, C8:0 significantly increased the TLR4 (Fig. 7a) and NF-kB (Fig. 7c) mRNA expression levels when supplemented at doses of $100 \mu \mathrm{mol} / \mathrm{L}$ and $200 \mu \mathrm{mol} / \mathrm{L}$ but reduced the TLR4 protein expression levels (Fig. $7 \mathrm{f}$ ) at the $100 \mu \mathrm{mol} / \mathrm{L}$ dose.

\section{Inflammatory cytokines and TLR4/NF-KB-related gene and} protein expression levels in TLR4-KD RAW246.7 cells

The comparison with the control group shown in Figs. 8, 9 suggested that significant reductions occurred in the TLR4-KD group in the inflammatory cytokine levels of TNF- $\alpha$ (decreased by $56 \%$ ), IL-1 $\beta$ (decreased by $63 \%$ ), IL- 6 (decreased by 67\%) and MCP-1 (decreased by 25\%), mRNA expression levels of the TLR4 (decreased by 38\%), MyD88 (decreased by $66 \%$ ), NF- $\mathrm{BB}$ (decreased by $73 \%$ ), and TNF- $\alpha$ (decreased by 79\%), and protein expression levels of the TLR4 (decreased by 45\%), MyD88 (decreased by 27\%), NF-kB (decreased by 29\%), and TNF- $\alpha$ (decreased by $10 \%$ ). However, inflammatory cytokine production of TNF- $\alpha$ (3.7-fold), IL-1 $\beta$ (8.0-fold), IL-6 (29.0-fold) and MCP-1 (3.3-fold) (Fig. 8a-d), mRNA expression levels of the MyD88 (1.9-fold), NF-kB (4.6-fold), and TNF- $\alpha$ (4.0-fold)

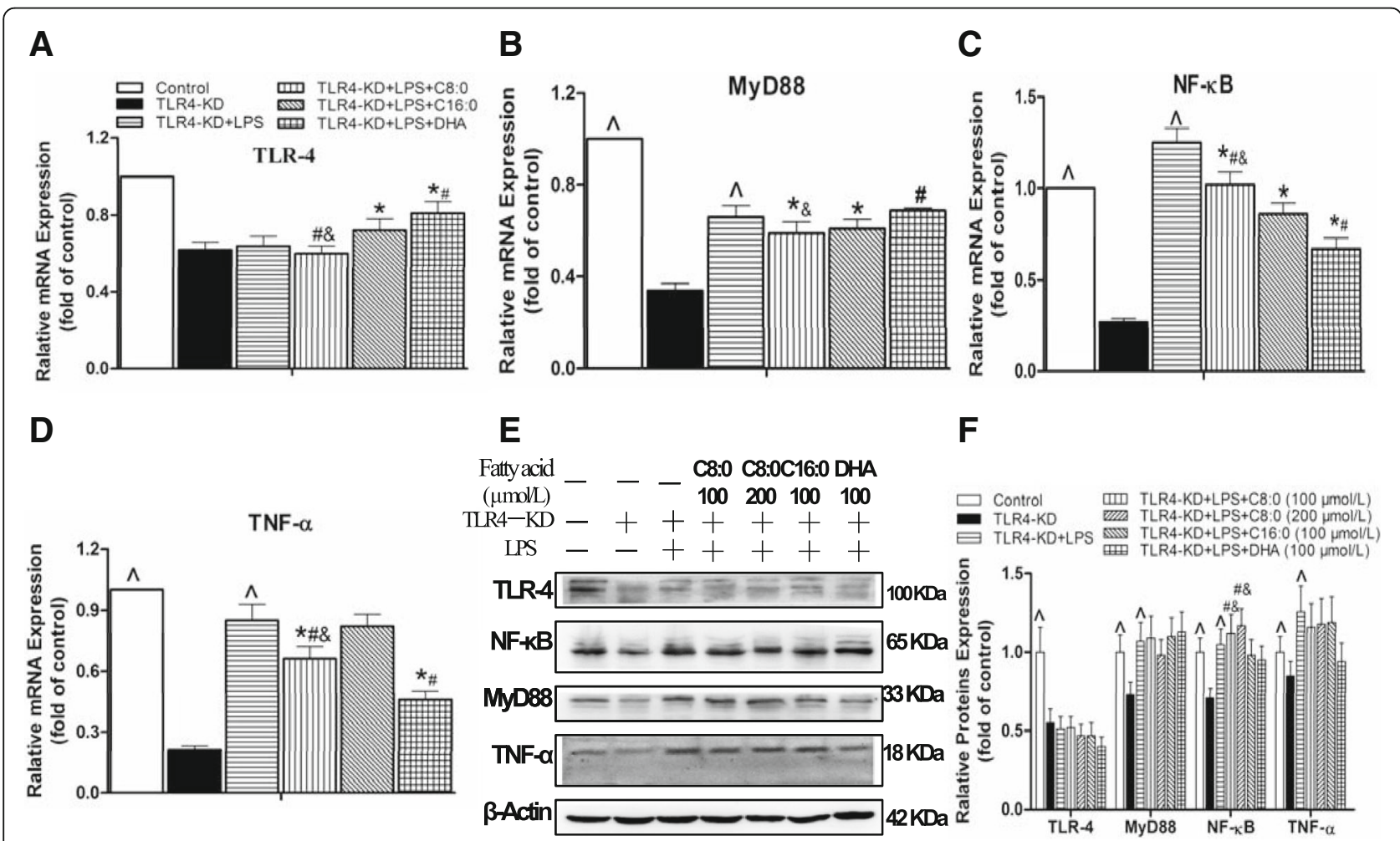

Fig. 9 The TLR4/NF-KB-related gene and protein expression levels in TLR4-KD RAW246.7 cells. The mRNA expression levels included (a) TLR-4, (b) MyD88, (c) NF-KB, (d) TNF-a. Relative protein expression was obtained from Western blot analysis and $\beta$-actin functioned as a control for loading: (e) bolt sections and $(\mathbf{f})$ gray-scale analysis. Data are mean \pm S. D of the mean $(n=6) .{ }^{\wedge} p<0.05$ versus TLR4-KD group; ${ }^{*} p<0.05$ versus TLR4-KD + LPS group; ${ }^{*} p<0.05$ versus TLR4-KD + LPS + C16:0 group; ${ }^{\&} p<0.05$ versus TLR4-KD + LPS + DHA group 
(Fig. 9a-d), and protein expression levels of the MyD88 (1.5-fold), NF-kB (1.5-fold) and TNF- $\alpha$ (1.4-fold) (Fig. 9f) were higher in the TLR4-KD + LPS group than in the TLR4-KD group. We further investigated the effects of different fatty acids on the TLR4-KD + LPS RAW246.7 cells and found that C8:0 at $100 \mu \mathrm{mol} / \mathrm{L}$ had inhibitory effects on TNF- $\alpha$ (decreased by 16\%) (Fig. 8a) and IL-1 $\beta$ (decreased by $16 \%$ ) (Fig. 8b), and downregulated mRNA expression of MyD88 (decreased by 11\%) (Fig. 9b), NF-kB (decreased by 18\%) (Fig. 9c), and TNF- $\alpha$ (decreased by 22\%) (Fig. 9d). Compared to those of the C16:0 group, C8:0 reduced the TNF- $\alpha$ (Fig. 8a) and IL-1 $\beta$ (Fig. 8b) levels and downregulated mRNA expression of TLR4 (Fig. 9a) and TNF- $\alpha$ (Fig. 9d), but up-regulated mRNA and protein expression of NF- $\mathrm{kB}$ (Fig. 9e, f). Compared to that of DHA, C8:0 significantly increased the IL-1 $\beta$ (Fig. 8b) and IL-6 (Fig. 8c) levels and downregulated mRNA expression levels of TLR4 (Fig. 9a) and MyD88 (Fig. 9b), but upregulated mRNA expression levels of NF-kB (Fig. 9c) and TNF- $\alpha$ (Fig. 9d). Moreover, the NF-kB (Fig. 9e, f) protein expression level was obviously increased.

\section{Discussion}

Herein, we explored the influences of C8:0 as a dietary supplement on the atherosclerotic lesion areas, serum cholesterol levels, and inflammation in $\mathrm{apoE}^{-1-}$ mice compared with mice administered C18:0 and C18:3. The results indicated that the inflammatory cytokine expression was inhibited, plasma lipid profiles were improved, and atherosclerosis was decreased in the presence of C8:0, which was in accordance with our previous observations on these mice [17]. Furthermore, we found that C8:0 suppressed inflammatory reactions through the TLR4/NF-kB signaling pathway.

\section{C8:0 has positive roles in atherosclerotic alleviation}

Many studies have elucidated the intimate relationship between atherosclerosis and fatty acids (either saturated or unsaturated). Omega-3, which is a type of unsaturated fatty acid, may prevent atherosclerotic progression and endothelial dysfunction, and can play a role in the regulation of atherosclerosis when administered as a supplement [25]. However, apart from sporadic reports with conflicting results, the effects of DHA supplementation on atherosclerotic lesion areas have rarely been studied. Dietary DHA can reduce the local expression of the pro-inflammatory cytokine $\mathrm{IL}-1 \beta$ in $\mathrm{apoE}^{-/-}$mice [26]. The $\mathrm{n}-3$ polyunsaturated fatty acid can modify the incorporation mode into tissues and inhibit hypoxia-induced atherosclerotic progression in $\mathrm{apoE}^{-/-}$mice [27]. Wang et al. [28] found that 10 weeks of n-3 PUFA fish oil supplementation alleviated atherosclerosis of the aortic root in $\mathrm{apoE}^{-1-}$ mice to a significant albeit limited extent. Conversely, some studies showed that supplementing chow with n-3 PUFAs for 14 [29] or 20 weeks [30] had little influence on the development of atherosclerotic lesions in apoE ${ }^{-/-}$mice. However, a review showed that n-3 PUFAs could prevent atherosclerotic morbidity, and evidence suggested that this effect might be mediated by improving endothelial dysfunction [31]. By surpassing the effects of oxidation and inflammatory stress, fats rich in linoleic acid can prevent atherosclerotic progression in apoE ${ }^{-/}$mice, compared to those fed a diet rich in saturated fatty acids [32]. Substituting excessive dietary SFAs for other types of macronutrients can contribute to early induction of atherosclerosis in animals [33]. Varying results have been reported in a great number of promising studies on the correlation of SFA intake with CVD [34]. Unlike LCFAs (>12 carbons), MCFAs can undergo rapid gastrointestinal hydrolysis and absorption, be directly transported via the portal veins, and undergo fast $\beta$-oxidation in the liver [35]. This metabolic specificity, which leads to enhanced catabolism but reduced tissue storage [36], was in relation to the physiological effects exerted by dietary MCFAs. It is reported to be beneficial or neutral compared to the metabolism of LCFAs. Some research also demonstrated that MCTs or MCFAs could play a positive role in reducing serum LDL-C and TC not only in mice $[37,38]$ but also in humans $[12,15,16,39]$. C8:0 is a type of MCFA, which we found could significantly reduce TC and LDL-C, compared to palmitic acid or stearic acid in apoE ${ }^{-/-}$mice [38]. C8:0 can also improve the HDL-C to LDL-C ratio and reduce the atherosclerotic extent in the aorta and aortic sinus [17]. These results suggested that C8:0 was similar to omega- 3 in terms of its positive roles in atherosclerotic alleviation.

\section{C8:0 inhibits inflammation}

As a chronic inflammatory disease, atherosclerosis progresses under the regulation of a large number of modulators, such as cytokines, eicosanoids [40], and dietary fatty acids, which represent another critical family of regulators [41]. SFAs [3, 4] and PUFAs, particularly n-6 PUFA [5], possess pro-inflammatory properties, as indicated by many studies performed both in vivo and in vitro. In contrast, n-3 PUFA, such as EPA and DHA, can exert anti-inflammatory effects $[42,43]$. MCFAs or MCTs can ameliorate inflammation. Bertevello et al. [44] achieved improvement in the colon cytokine response and damage reduction in model rats with colitis by partially replacing the $\mathrm{n}-6$ fatty acids with MCTs. Papada et al. [45] reported the anti-inflammatory performance of a diet rich in MCTs in model rats carrying TNBS-induced colitis, in which the IL-6, IL-8, and intercellular adhesion molecule-1 levels were decreased and glutathione $\mathrm{S}$-transferase activity was reduced. Moreover, for a model rat carrying sepsis, an MCT diet could significantly reduce the expression levels of pro-inflammatory cytokines and chemokines (TNF- $\alpha$, 
IL-18, macrophage inflammatory protein-2, and MCP-1) in the ileum and Peyer's patches [46]. Herein, C8:0 has been proven to be prominently efficient in inhibiting inflammatory cytokine expression (i.e., TNF- $\alpha$ and MCP-1) in the plasma, and increasing the IL-10 level compared with those of the group treated with C18:0. However, a minor discrepancy was noted between the C8:0 and C18:3 groups. One meta-analysis reported that C18:3 administration had great therapeutic potential via decreasing patients' inflammatory markers (e.g., C-reactive protein, IL-6, and TNF- $\alpha$ ) that were associated with metabolic syndrome and related diseases [47]. Samantha et al. [48] also found that $\mathrm{C} 18: 3$ might function to alleviate the inflammatory states of M1-like macrophages via a special pathway that was different from those associated with EPA and DHA. Martínez-Micaelo et al. [49] confirmed that SFAs activated the nod-like receptor protein 3 inflammasome and stimulated IL- $1 \beta$ secretion, whereas DHA ( $n-3$ PUFA) functioned more positively than arachidonic acid in terms of inhibition of inflammasome activation. In vitro studies showed that levels of the inflammatory cytokines TNF- $\alpha$ and IL-1 $\beta$ increased with prolongation of LPS stimulation, compared with those of control group, possibly due to increased cell stress and apoptosis. However, C8:0 inhibited production of TNF- $\alpha$, IL-1 $\beta$, IL-6, and MCP-1 in RAW246.7 cells activated by LPS, and the effects were significantly greater when treated with $100 \mu \mathrm{mol} / \mathrm{L}$ and $24 \mathrm{~h}$. Moreover, these observations were similar to those for the DHA group. The effects of MCFAs have also been discussed recently. Tanaka et al. [50] reported the potentiation of C10:0 on IL-8 production in Caco- 2 cells stimulated by IL- $1 \beta$. Hoshimoto et al. [51] first discovered that IL-8 secretion from Caco-2 cells could be suppressed by C8:0 as well as medium-chain C8 triglycerides. These results suggested that $\mathrm{C} 8: 0$, but not C10:0, inhibited inflammation. However, the mechanisms through which C8:0 dampens inflammation remain unclear.

C8:0 can suppress inflammation via TLR4/NF-KB signaling Several studies have confirmed that inflammatory responses mediated by TLR4 may impose significant effects on the initiation and subsequent progression of atherosclerosis $[21,52]$. We noted previously that MCTs could ameliorate atherosclerosis via promotion of reverse cholesterol transport [17], which increased the ease of cholesterol export from peripheral cells and prevented intracellular cholesterol accumulation. In this study, we found that C8:0, which is a member of the MCFAs, could suppress inflammatory signaling via the TLR4/NF- $\mathrm{B}$ pathway and improve atherosclerosis in apoE ${ }^{-/-}$mice. TLRs can regulate both sterile inflammation and that induced by infection via endogenous molecules. Upon LPS binding, the TLR4/CD14/LBP receptor complex engages MyD88 to initiate a downstream signaling cascade, thereby triggering NF- $\mathrm{kB}$ and activating genes that encode pro-inflammatory factors, such as cytokines and COX2 [53]. Numerous reports have investigated the stimulatory effects of SFAs on inflammatory responses via a TLR4-involved pathway. In particular, the stimulatory effects of the SFAs C12:0, C16:0, and C18:0 can enhance expression levels of the IL- 6 gene in macrophages through this approach [54]. In accordance, MCP-1 expression can also be enhanced by C18:0 via TLR4 [55]. In this study, we showed that C8:0 significantly downregulated the mRNA expression levels of TLR4, MyD88, NF- $\kappa$ B, TNF- $\alpha$, TAK1, IKK $\alpha$, and IKK $\beta$ compared to those induced by $\mathrm{C} 18: 0$ in the aortas of apoE ${ }^{-/-}$mice. Macrophages are the most abundant immune cell type and primary inflammatory cells in atherosclerotic lesions and have an essential role during all stages of atherosclerosis [56]. Excessive lipid accumulation in macrophages, also known as foam cell formation, is a key process during the development of atherosclerosis, leading to vascular inflammation and plaque growth. The expression of TLR4 has been found in macrophages and endothelial cells within human and mouse atherosclerotic lesions; and the TLR4 deficiency significantly reduces the in vivo rate of macrophage lipid accumulation in vascular lesions [57]. The inflammatory responses mediated by TLR4 play important roles in the initiation and progression of atherosclerosis. Therefore, we further observed the effect of C8:0 on the TLR4/ NF- $\kappa B$ pathway of macrophages. The assay results obtained from RAW246.7 cells were consistent. Our data showed an altered effect of C8:0 on TLR4 even as a saturated fatty acid, which was different from that of the LCFAs. Furthermore, two pathways have been proposed to underlie the mechanism of SFA-mediated inflammation (i.e., a TLR4-dependent one and a TLR4-independent pathway) [58, 59]. Whereas SFAs can stimulate TLR4 signaling, EPA and DHA have been suggested to play inhibitory roles [60]. The first possibility is that EPA and DHA bind to G protein-coupled receptor 120 , thereby inhibiting TAK1 and preventing the downstream NF-kB and JNK signaling pathways [6]. Other explanations for the anti-inflammatory roles played by EPA and DHA include altered phospholipid fatty acid compositions in cell membranes, lipid rafts damage, downregulation of nicotinamide adenine dinucleotide phosphate-oxidase production, upregulation of PPAR $\gamma$ activation, and inhibition of activation of NF- $\mathrm{kB}$, which is a pro-inflammatory factor for transcription [58]. Although SFAs can activate TLR4, the polyunsaturated fatty acids, especially DHA and EPA, may exert opposite effects [60]. We attempted to clarify the mechanism through which C8:0 suppressed the inflammatory reaction via TLR4/NF-kB signaling. In TLR4-KD 
RAW264.7 cells, it functioned adversely to the effects of C8:0 on inflammatory cytokines; and the effects were different from those observed without TLR4-KD. We also found a remarkable upregulation effect of C8:0 on the NF- $\mathrm{kB}$ mRNA and protein expression levels compared to those detected in the presence of C16:0. Despite the downregulation of TLR4 and MyD88 mRNA expression induced by $\mathrm{C} 8: 0$, it significantly strengthened TNF- $\alpha$ and IL-1 $\beta$ expression, increased TNF- $\alpha$ and NF- $\kappa B$ mRNA expression, and elevated NF- $\kappa B$ expression compared with those obtained in the presence of DHA. These results indicated that C8:0 might affect TLR4-mediated inflammatory responses. However, the mechanism through which C8:0 inhibits TLR4 is not clearly understood. Therefore, further research is needed to determine this mechanism.

\section{Implications and limitations}

There are some strengths of our study. Firstly, MCTs, mainly containing saturated fatty acids, can inhibit inflammation in $\mathrm{ApoE}^{-1-}$ mice. Secondly, that anti-inflammatory effect of medium chain fatty acids is mainly C8:0, but not C10:0 in $\mathrm{ApoE}^{-/-}$mice. Last, this work should be the first case to indicate that C8:0-mediated inhibition of TLR4/ NF- $\mathrm{KB}$ signaling may improve atherosclerosis. It provides a theoretical basis for the prevention of chronic inflammatory diseases by C8:0.

\section{- inhibition \\ $\rightarrow$ activation}

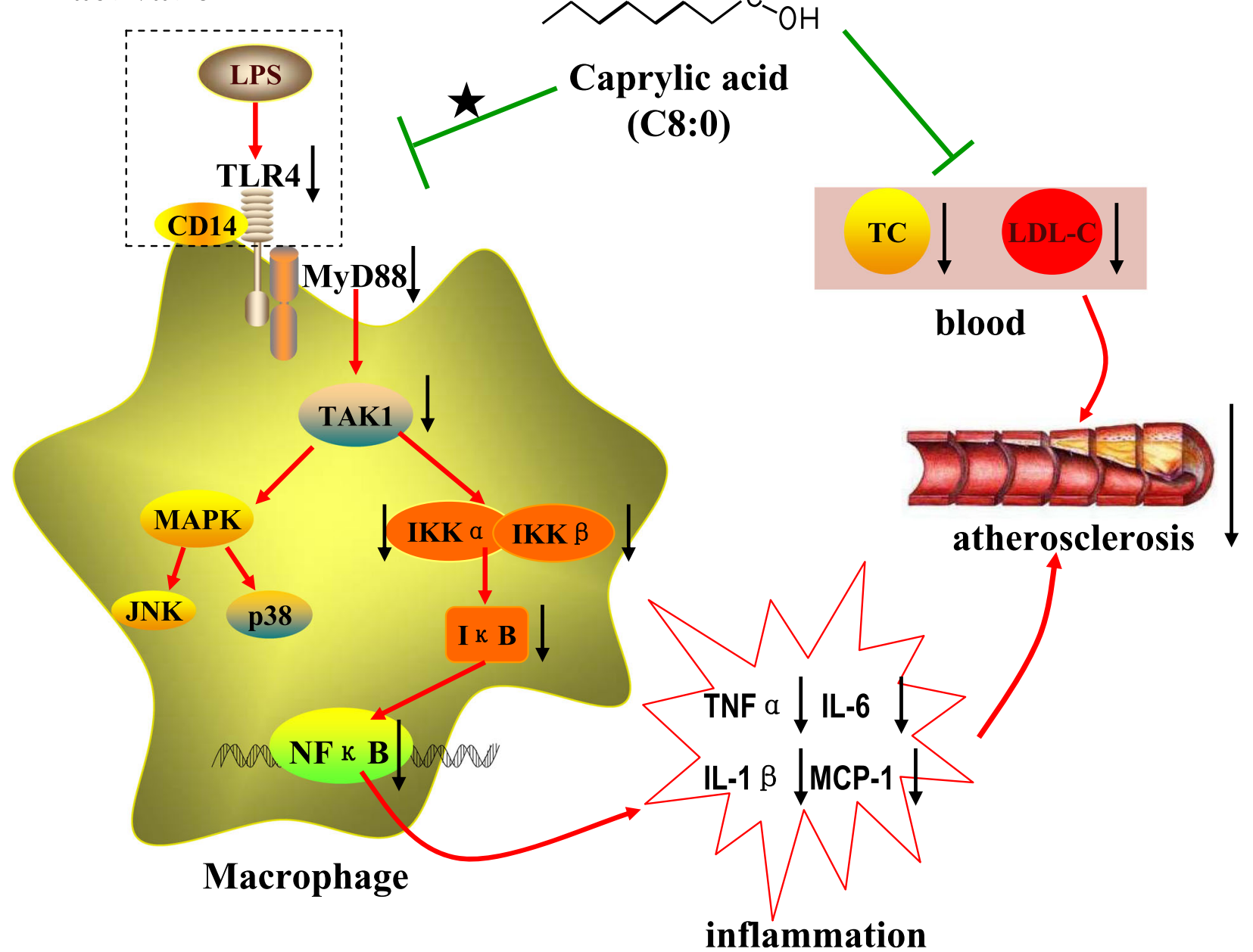

Fig. 10 The proposed mechanism underlying the effects of C8:0 on inhibiting inflammation and reducing the atherosclerotic. Arrows ( $\downarrow$ ) represent a decreasing level and downregulation of activity or protein or mRNA expression. The " $\star$ " indicate the manner in which C8:0 acts on TLR4 or macrophage is unclear. LPS, lipopolysaccharide; TLR4, toll-like receptor 4; MyD88, myeloid differentiation primary response 88; NF-KB, nuclear factor kappa B; TNF-a, tumor necrosis factor alpha; TAK1, TGF- $\beta$-activated kinase 1; MAPK, mitogen-activated protein kinase; JNK, c-Jun N-terminal kinase; IKKa, inhibitor kappa B kinase a; IKK $\beta$, inhibitor kappa B kinase $\beta$; IL-1 $\beta$, interleukin-1 $\beta$; IL-6, interleukin-6; MCP-1, monocyte chemoattractant protein-1; TC, total cholesterol; LDL-C, low density lipoprotein cholesterol 
This study had some limitations. (1) We should have examined whether C8:0 had any effects on inflammation and atherosclerosis in TLR4 ${ }^{-/-}$ApoE-KO mice or in $\mathrm{ApoE}^{-/-}$mice treated with a TLR4 siRNA. Additionally, these experiments do not indicate that the same effects will occur in humans. Therefore, further clinical studies are warranted. (2) Research on the mechanisms through which C8:0 regulates TLR4 is limited. The specific protein-coupled receptor to which C8:0 binds and the mechanism through which C8:0 binds TLR4 are not known. Although C8:0 can inhibit the TLR4/NF-kB signaling pathways to suppress inflammation, this inhibition occurs through MyD88-dependent and/or MyD88-independent pathways is uncertain. (3) TLR4 expression has been found to be broad in many cell types in the vessel wall that are related to atherosclerotic pathogenesis. However, the evaluation of how C8:0 affected TLR4 expression in both endothelial and vascular smooth muscle cells on the vessel wall was insufficient in this work. (4) Other probable mechanisms may exist besides the TLR4/NF- $\mathrm{KB}$ inhibition that underlies the C8:0-mediated dampening of the inflammatory response and improvement of atherosclerosis.

\section{Conclusion}

Our results suggested that C8:0 supplementation confers protection against atherosclerosis through suppression of inflammation and improvement of blood lipids. The anti-inflammatory efficacy of C8:0 was mediated by downregulation of TLR4 and suppression of the NF- $\kappa B$ signaling pathways (Fig. 10). These findings indicated that C8:0 may be a potential candidate for ameliorating and preventing atherosclerosis and related chronic inflammatory diseases.

\section{Additional files}

Additional file 1: Compositions of applied diets (g/kg). (PDF 24 kb)

Additional file 2: Compositions of fatty acids in the applied diets ( $\mathrm{g} / \mathrm{kg}$ ). (PDF $7 \mathrm{~kb}$ )

\section{Abbreviations}

ApoE $^{-/-}$: ApoE-deficient; DHA: Docosahexenoic acid; DMEM: Dulbecco's modified Eagle medium; EPA: Eicosapentaenoic acid; HDL-C: High density lipoprotein cholesterol; HFD: High-fat diet; IKKa: Inhibitor of nuclear factor

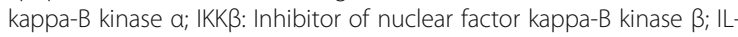
10: Interleukin-10; IL-13: Interleukin-1 $\beta$; IL-2: Interleukin-2; IL-6: Interleukin-6; LCFAs: Long-chain saturated fatty acids; LDL-C: Low density lipoprotein cholesterol; LPS: Lipopolysaccharide; MAPK: Mitogen-activated protein kinase; MCFAs: Medium-chain fatty acids; MCP-1: Monocyte chemoattractant protein-1; MCTs: Medium-chain triglycerides; MyD88: Myeloid differentiation primary response gene 88; NF-kB: Nuclear factor kappa B; PCR: Polymerase chain reaction; PUFA: Polyunsaturated fatty acids; SFAs: Saturated fatty acids; TAK1: Transforming growth factor activated kinase-1; TC: Total cholesterol; TG: Triglyceride; TLR4: Toll-like receptor 4; TLR4-KD: TLR4 knock-down; TNFa: Tumor necrosis factor a; C8:0: Caprylic acid; C10:0: Capric acid;

C16:0: Palmitic acid; C18:0: Stearic acid; C18:1: Oleic acid; C18:3: Linolenic acid

\section{Acknowledgements}

We thank Yajun Lin (Beijing Geriatric Institute of Beijing Hospital) for his kind technical support.

\section{Funding}

This work was supported by the National Natural Science Fund of China (no. 81541067 and 81703204).

\section{Availability of data and materials}

Please contact author (Xinsheng Zhang) for data or material requests.

\section{Authors' contributions}

$C G$ and $Y L$ designed the research and provided research funding. $X S, C X, Q X$ $Y Z, H L$ and FL conducted the research. XS and YL analysed the data. XS wrote the first draft. All authors read and approved the final manuscript.

\section{Ethics approval}

All the operations in designed experiments were with the approval from the Animal Care and Use Committee of the Chinese PLA General Hospital. Surgeries were conducted with anesthesia of xylazine hydrochloride, and every effort had been made for suffering minimization.

\section{Consent for publication}

The authors consent to the publication of the data.

\section{Competing interests}

The authors declare that they have no competing interests.

\section{Publisher's Note}

Springer Nature remains neutral with regard to jurisdictional claims in published maps and institutional affiliations.

\section{Author details}

${ }^{1}$ Department of Nutrition, Tianjin Institute of Environmental \& Operational Medicine, Tianjin 300050, China. ${ }^{2}$ Department of Nutrition, Chinese PLA General Hospital, 28 Fuxing Road, Beijing 100853, China. ${ }^{3}$ Department of Nutrition, PLA Rocket Force Characteristic Medical Center, Beijing 100088 China. ${ }^{4}$ Department of Nutrition, Air Force Medical Center, PLA, Beijing 100142, China

Received: 10 February 2019 Accepted: 1 May 2019

Published online: 06 June 2019

\section{References}

1. Taleb S. Inflammation in atherosclerosis. Archives of cardiovascular diseases. 2016;109:708-15.

2. Wu MY, Li CJ. New insights into the role of inflammation in the pathogenesis of atherosclerosis. Int J Mol Sci. 2017. https://doi.org/10.3390/ ijms18102034.

3. Chavez JA, Summers SA. Characterizing the effects of saturated fatty acids on insulin signaling and ceramide and diacylglycerol accumulation in 3T3-L1 adipocytes and C2C12 myotubes. Arch Biochem Biophys. 2003;419:101-9.

4. Wang Z, Liu D, Wang F, Liu S, Zhao S, Ling EA, Hao A. Saturated fatty acids activate microglia via toll-like receptor 4/NF-KB signaling. Br J Nutr. 2012; 107:229-41.

5. Calder PC. Omega-3 fatty acids and inflammatory processes: from molecules to man. Biochem Soc Trans. 2017:45:1105-15.

6. Oh DY, Talukdar S, Bae EJ, Imamura T, Morinaga H, Fan W, Li P, Lu WJ, Watkins SM, Olefsky JM. GPR120 is an Omega-3 fatty acid receptor mediating potent anti-inflammatory and insulin sensitizing effects. Cell. 2010;142:687-98.

7. De Oliveira Otto MC, Wu JH, Baylin A, Vaidya D, Rich SS, Tsai MY, Jacobs DR Jr, Mozaffarian D. Circulating and dietary omega-3 and omega-6 polyunsaturated fatty acids and incidence of CVD in the multi-ethnic study of atherosclerosis. J Am Heart Assoc. 2013;2:e000506.

8. Decuypere JA, Dierick NA. The combined use of triacylglycerols containing medium-chain fatty acids and exogenous lipolytic enzymes as an alternative to in-feed antibiotics in piglets: concept, possibilities and limitations. An overview. Nutr Res Rev. 2003;16:193-210. 
9. Kaunitz H. Medium chain triglycerides (MCT) in aging and arteriosclerosis. Environ Pathol Toxicol Oncol. 1986;6:115-21.

10. Nosaka N, Maki H, Suzuki Y, Haruna H, Ohara A, Kasai M, Tsuji H, Aoyama T, Okazaki M, Igarashi $\mathrm{O}$. Effects of margarine containing medium-chain triacylglycerols on body fat reduction in humans. J Atheroscler Thromb. 2003;10:290-8.

11. Rego Costa AC, Rosado EL, Soares-Mota M. Influence of the dietary intake of medium chain triglycerides on body composition, energy expenditure and satiety: a systematic review. Nutr Hosp. 2012;27:103-8.

12. Xue C, Liu Y, Wang J, Zhang R, Zhang Y, Zhang J, Zhang Z, Yu X, Jing H, Nosaka N. Consumption of medium- and long-chain triacylglycerols decreases body fat and blood triglyceride in Chinese hypertriglyceridemic subjects. Eur J Clin Nutr. 2009;63:879-86.

13. Bourque C, St-Onge MP, Papamandjaris AA, Cohn JS, Jones PJ. Consumption of an oil composed of medium chain triacyglycerols, phytosterols, and N-3 fatty acids improves cardiovascular risk profile in overweight women. Metabolism. 2003:52:771-7.

14. Cox C, Sutherland W, Mann J, de Jong S, Chisholm A, Skeaff M. Effects of dietary coconut oil, butter and safflower oil on plasma lipids, lipoproteins and lathosterol levels. Eur J Clin Nutr. 1998;52:650-4.

15. St-Onge MP, Lamarche B, Mauger JF, Jones PJ. Consumption of a functional oil rich in phytosterols and medium-chain triglyceride oil improves plasma lipid profiles in men. J Nutr. 2003;133:1815-20.

16. Liu Y, Wang J, Zhang R, Zhang Y, Xu Q, Zhang J, Zhang Z, Yu X, Jing H, Nosaka N. A good response to oil with medium- and long-chain fatty acids in body fat and blood lipid profiles of male hypertriglyceridemic subjects. Asia Pac J Clin Nutr. 2009;18:351-8.

17. Zhang $X$, Zhang Y, Liu Y, Wang J, Xu Q, Yu X, Yang X, Liu Z, Xue C. Medium-chain triglycerides promote macrophage reverse cholesterol transport and improve atherosclerosis in ApoE-deficient mice fed a high-fat diet. Nutr Res. 2016;36:964-73.

18. Xing S, Zheng F, Zhang W, Wang D, Xing Q. Relationship between toll-like receptor 4 levels in aorta and severity of atherosclerosis. J Int Med Res. 2014;42:958-65.

19. Bowman JD, Surani S, Horseman MA. Endotoxin, toll-like Receptor-4, and atherosclerotic heart disease. Curr Cardiol Rev. 2017:13:86-93.

20. Pryshchep O, Ma-Krupa W, Younge BR, Goronzy JJ, Weyand CM. Vesselspecific toll-like receptor profiles in human medium and large arteries. Circulation. 2008:118:1276-84.

21. Michelsen KSWM, Shah PK, Zhang W, Yano J, Doherty TM, Akira S, Rajavashisth TB, Arditi M. Lack of toll-like receptor 4 or myeloid differentiation factor 88 reduces atherosclerosis and alters plaque phenotype in mice deficient in apolipoprotein E. Proc Natl Acad Sci U S A. 2004;101:10679-84.

22. Kim HY, Kim JH, So Y, Kang SY, Jeong HG, Jin CH. Anti-inflammatory effect of Lupinalbin a isolated from Apios americana on lipopolysaccharidetreated RAW264.7 cells. Molecules. 2018. https://doi.org/10.3390/ molecules23030583.

23. Nagao K, Yanagita T. Medium-chain fatty acids: functional lipids for the prevention and treatment of the metabolic syndrome. Pharmacol Res. 2010; 61:208-12.

24. Tsuji H, Kasai M, Takeuchi H, Nakamura M, Okazaki M, Kondo K. Dietary medium-chain triacylglycerols suppress accumulation of body fat in a doubleblind, controlled trial in healthy men and women. J Nutr. 2001;131:2853-9.

25. Verveniotis ASG, Oikonomou E, Tsigkou V, Papageorgiou N, Zaromitidou M, Psaltopoulou T, Marinos G, Deftereos S, Vavuranakis M, Stefanadis C, Papavassiliou AG, Tousoulis D. The impact of omega 3 fatty acids in atherosclerosis and arterial stiffness: an overview of their actions. Curr Pharm Des. 2018;24:1865-72.

26. Alfaidi MA, Chamberlain J, Rothman A, Crossman D, Villa-Uriol MC, Hadoke P, Wu J, Schenkel T, Evans PC, Francis SE. Dietary docosahexaenoic acid reduces Oscillatory Wall shear stress, atherosclerosis, and hypertension, Most likely mediated via an IL-1-mediated mechanism. J Am Heart Assoc. 2018. https://doi.org/10.1161/jaha.118.008757.

27. Van Noolen L, Back M, Arnaud C, Rey A, Petri MH, Levy P, Faure P, StankeLabesque F. Docosahexaenoic acid supplementation modifies fatty acid incorporation in tissues and prevents hypoxia induced-atherosclerosis progression in apolipoprotein-E deficient mice. Prostaglandins Leukot Essent Fatty Acids. 2014;91:111-7.

28. Wang HH, Hung TM, Wei J, Chiang AN. Fish oil increases antioxidant enzyme activities in macrophages and reduces atherosclerotic lesions in apoE-knockout mice. Cardiovasc Res. 2004;61:169-76.
29. $\mathrm{Xu} \mathrm{Z}$, Riediger N, Innis S, Moghadasian MH. Fish oil significantly alters fatty acid profiles in various lipid fractions but not atherogenesis in apo E-KO mice. Eur J Nutr. 2007;46:103-10.

30. Zampolli A, Bysted A, Leth T, Mortensen A, De Caterina R, Falk E. Contrasting effect of fish oil supplementation on the development of atherosclerosis in murine models. Atherosclerosis. 2006;184:78-85.

31. Zehr KR, Walker MK. Omega-3 polyunsaturated fatty acids improve endothelial function in humans at risk for atherosclerosis: a review. Prostaglandins \& other lipid mediators. 2018;134:131-40.

32. Sato M, Shibata K, Nomura R, Kawamoto D, Nagamine R, Imaizumi K. Linoleic acid-rich fats reduce atherosclerosis development beyond its oxidative and inflammatory stress-increasing effect in apolipoprotein Edeficient mice in comparison with saturated fatty acid-rich fats. Br J Nutr. 2005;94:896-901.

33. Koopmans SJ, Dekker R, Ackermans MT, Sauerwein HP, Serlie MJ, van Beusekom HM, van den Heuvel M, van der Giessen WJ. Dietary saturated fat/cholesterol, but not unsaturated fat or starch, induces Creactive protein associated early atherosclerosis and ectopic fat deposition in diabetic pigs. Cardiovasc Diabetol. 2011;10:64.

34. Siri-Tarino PW, Sun Q, Hu FB, Krauss RM. Meta-analysis of prospective cohort studies evaluating the association of saturated fat with cardiovascular disease. Am J Clin Nutr. 2010;91:535-46.

35. Bach AC, Babayan VK. Medium-chain triglycerides: an update. Am J Clin Nutr. 1982;36:950-62.

36. Bach AC, Ingenbleek $Y$, Frey A. The usefulness of dietary medium-chain triglycerides in body weight control: fact or fancy? J Lipid Res. 1996;37:708-26.

37. Nagata J, Kasai M, Negishi S, Saito M. Effects of structured lipids containing eicosapentaenoic or docosahexaenoic acid and caprylic acid on serum and liver lipid profiles in rats. Biofactors. 2004;22:157-60.

38. Xu Q, Xue C, Zhang Y, Liu Y, Wang J, Yu X, Zhang X, Zhang R, Yang X, Guo C. Medium-chain fatty acids enhanced the excretion of fecal cholesterol and cholic acid in C57BL/6J mice fed a cholesterol-rich diet. Biosci Biotechnol Biochem. 2013;77:1390-6.

39. St-Onge MP, Bosarge A, Goree LL, Darnell B. Medium chain triglyceride oil consumption as part of a weight loss diet does not lead to an adverse metabolic profile when compared to olive oil. J Am Coll Nutr. 2008;27:547-52.

40. Hansson GK. Inflammation, atherosclerosis, and coronary artery disease. N Engl J Med. 2005;352:1685-95.

41. Casas R, Estruch R. Influence of bioactive nutrients on the atherosclerotic process: a review. Nutrients. 2018. https://doi.org/10.3390/nu10111630.

42. Rogero MM, Calder PC. Obesity, inflammation, toll-like receptor 4 and fatty acids. Nutrients. 2018. https://doi.org/10.3390/ijms18102034.

43. Vijay-Kumar M, Vanegas SM, Patel N, Aitken JD, Ziegler TR, Ganji V. Fish oil rich diet in comparison to saturated fat rich diet offered protection against lipopolysaccharide-induced inflammation and insulin resistance in mice. Nutr Metab (Lond). 2011;8:16.

44. Bertevello PL, De Nardi L, Torrinhas RS, Logullo AF, Waitzberg DL. Partial replacement of $\omega-6$ fatty acids with medium-chain triglycerides, but not olive oil, improves colon cytokine response and damage in experimental colitis. JPEN J Parenter Enteral Nutr. 2012;36:442-8.

45. Papada E, Kaliora AC, Gioxari A, Papalois A, Forbes A. Anti-inflammatory effect of elemental diets with different fat composition in experimental colitis. Br J Nutr. 2014;111:1213-20.

46. Kono H, Fujii H, Asakawa M, Maki A, Amemiya H, Hirai Y, Matsuda M, Yamamoto M. Medium-chain triglycerides enhance secretory lgA expression in rat intestine after administration of endotoxin. Am J Physiol Gastrointest Liver Physiol. 2004;286:G1081-9.

47. Akbari M, Ostadmohammadi V, Tabrizi R, Mobini M, Lankarani KB, Moosazadeh M, Heydari ST, Chamani M, Kolahdooz F, Asemi Z. The effects of alpha-lipoic acid supplementation on inflammatory markers among patients with metabolic syndrome and related disorders: a systematic review and meta-analysis of randomized controlled trials. Nutr Metab (Lond). 2018;15:39.

48. Pauls SD, Rodway LA, Winter T, Taylor CG, Zahradka P, Aukema HM. Antiinflammatory effects of alpha-linolenic acid in M1-like macrophages are associated with enhanced production of oxylipins from alpha-linolenic and linoleic acid. J Nutr Biochem. 2018;57:121-9.

49. Martinez-Micaelo N, Gonzalez-Abuin N, Pinent M, Ardevol A, Blay M. Dietary fatty acid composition is sensed by the NLRP3 inflammasome: omega-3 fatty acid (DHA) prevents NLRP3 activation in human macrophages. Food Funct. 2016;7:3480-7. 
50. Tanaka S, Saitoh O, Tabata K, Matsuse R, Kojima K, Sugi K, Nakagawa K, Kayazawa M, Teranishi T, Uchida K. Medium-chain fatty acids stimulate interleukin-8 production in Caco-2 cells with different mechanisms from long-chain fatty acids. J Gastroenterol Hepatol. 2001:16:748-54.

51. Hoshimoto A, Suzuki Y, Katsuno T, Nakajima H, Saito Y. Caprylic acid and medium-chain triglycerides inhibit IL-8 gene transcription in Caco-2 cells: comparison with the potent histone deacetylase inhibitor trichostatin a. Br J Pharmacol. 2002;136:280-6.

52. Jia SJ, Niu PP, Cong JZ, Zhang BK, Zhao M. TLR4 signaling: a potential therapeutic target in ischemic coronary artery disease. Int Immunopharmacol. 2014;23:54-9.

53. Sabroe I, Parker LC, Dower SK, Whyte MK. The role of TLR activation in inflammation. J Pathol. 2008;214:126-35

54. Shi H, Kokoeva MV, Inouye K, Tzameli I, Yin H, Flier JS. TLR4 links innate immunity and fatty acid-induced insulin resistance. J Clin Invest. 2006;116: 3015-25.

55. Schaeffler A, Gross P, Buettner R, Bollheimer C, Buechler C, Neumeier M, Kopp A, Schoelmerich J, Falk W. Fatty acid-induced induction of toll-like receptor-4/nuclear factor-kappaB pathway in adipocytes links nutritional signalling with innate immunity. Immunology. 2009;126:233-45.

56. Cochain C, Zernecke A. Macrophages in vascular inflammation and atherosclerosis. Pflugers Archiv. 2017:469:485-99.

57. Miller YI, Choi SH, Fang L, Harkewicz R. Toll-like receptor-4 and lipoprotein accumulation in macrophages. Trends Cardiovasc Med. 2009;19:227-32.

58. Teng KT, Chang CY, Chang LF, Nesaretnam K. Modulation of obesityinduced inflammation by dietary fats: mechanisms and clinical evidence. Nutr J. 2014;13:12.

59. Olefsky JM, Glass CK. Macrophages, inflammation, and insulin resistance. Annu Rev Physiol. 2010;72:219-46.

60. Hwang DH, Kim JA, Lee JY. Mechanisms for the activation of toll-like receptor $2 / 4$ by saturated fatty acids and inhibition by docosahexaenoic acid. Eur J Pharmacol. 2016;785:24-35

Ready to submit your research? Choose BMC and benefit from:

- fast, convenient online submission

- thorough peer review by experienced researchers in your field

- rapid publication on acceptance

- support for research data, including large and complex data types

- gold Open Access which fosters wider collaboration and increased citations

- maximum visibility for your research: over $100 \mathrm{M}$ website views per year

At $\mathrm{BMC}$, research is always in progress.

Learn more biomedcentral.com/submissions 